\title{
In vitro Evaluation of Various Fungicides against Erysiphe cichorocearum in Polyhouse
}

\author{
S.M. Wahul", G.P. Jagtap, K.A. Rewale and R.P. Bhosale \\ Department of Plant Pathology, College of agriculture, Vasantrao Naik Marathwada Krishi \\ Vidyapeeth, Parbhani (MH), India \\ *Corresponding author
}

\section{A B S T R A C T}

Cucumber (Cucumis sativus L.) is belongs to family cucurbitaceae is one of the most popular and favorite vegetable crops in different parts of the world. The family has two subfamilies and includes 118 genera and 825 species (Judd et al., 2008). Most species are climbing perennial herbs. The family is important for edible fruits (Heywood et al., 2007; Judd et al., 2008). It is used either as fresh fruits or in pickling industry. Cucumber

\section{Key words}

Cucumber, Erysiphe cichoracearum,

Hexaconazole, Efficacy

\section{Article Info}

Accepted:

12 September 2018 Available Online: 10 October 2018 contains 0.4 per cent protein, 2.5 per cent carbohydrates, $1.5 \mathrm{mg}$ iron, and $2 \mathrm{mg}$ of vitamin $\mathrm{C}$ in $100 \mathrm{mg}$ of fresh weight. Fruits are good for people suffering from constipation, jaundice and indigestion (Anonymous, 2014). Powdery mildew caused by Erysiphe cichoracearum (D.C.) is an important disease of cucurbits, particularly; cucumber is highly susceptible to this disease and suffers heavy losses in all localities of Maharashtra State, wherever it is grown. Cucumbers have been grown in India for more than 3000 years and around 2000 B.C. was brought to the area around the Mediterranean Sea and Egypt (Bjelland, 1988). Results of field efficacy of fungicides against powdery mildew indicated that disease incidence and disease intensity were declined only after second and third sprays. Disease incidence and per cent disease intensity after third treatment spray (85 DAS) was recorded in the range of 19.46 to 41.26 per cent and 27.30 to 74.66 per cent PDI, respectively as against unsprayed control. The fungicide hexaconazole $(0.1 \%)$ showed significantly lowest disease incidence $(19.46 \%)$ and disease intensity $(27.30 \%)$ with maximum $(61.85 \%)$ mean per cent disease control. On the basis of effectiveness in controlling the powdery mildew disease of Cucumber, the most effective fungicides recorded in the order of merit were hexaconazole $(0.1 \%)$, propiconazole $(0.1 \%)$ and

\section{Introduction}

Vegetables form an essential component of human diet for maintenance of good health. They supply carbohydrates, proteins, fats, vitamins, and mineral elements which are the most essential requirements of our body. At present cucumber is grown in an area of 2,090 thousand hectares with a production of 65.33 million tones and productivity of $31.25 \mathrm{t} / \mathrm{ha}$ in the world (vegetable statistics), whereas in India it is grown in an area of 43,280 hectares with a production of $6,78,150$ tones and productivity of $15.67 \mathrm{t} / \mathrm{ha}$ (NHB-Database) in Himachal Pradesh, separate figures for area and production of cucumber are not available. 
However cucurbits as a whole are cultivated in 2,436 hectares with an annual production and productivity of 62,169 tones and $25.52 \mathrm{t} / \mathrm{ha}$, respectively and cucumber contributes to 70 80 per cent of total area and production of cucurbits in Himachal Pradesh (vegetable statistics).Powdery mildew caused by Erysiphe cichoracearum (D.C.) is an important disease of cucurbits, particularly; cucumber is highly susceptible to this disease and suffers heavy losses in all localities of Maharashtra State, wherever it is grown. Cucumber is found wild in Himalaya and in northern India (Molen, 2007/2008). Cucumbers have been grown in India for more than 3000 years and around 2000 B.C. was brought to the area around the Mediterranean Sea and Egypt (Bjelland, 1988).

\section{Materials and Methods}

The field experiment was carried out to evaluate the efficacy of seven fungicides with one check (unsprayed) for the control of powdery mildew disease of Cucumber. Three treatment sprayings were undertaken, First treatment sprays was done immediately after initiation of disease symptoms (55 DAS) and subsequent treatment sprays at an interval of 15 days were given and observations on disease incidence and disease intensity were recorded at 55 days, 70 days and 85 days after sowing. Following fungicide were obtained from department of plant pathology, VNMKV, Parbhani.

\section{Results and Discussion}

\section{Effect on powdery mildew disease incidence}

The results obtained during Kharif, 2015 revealed that all the treatments were significantly superior over unsprayed control (Table 1 and Fig. 1). All the treatments recorded significantly low disease incidence over control at 55 DAS, 70 DAS and 85 DAS.
The treatment $\mathrm{T}_{2}$ i.e., Hexaconazole was found significantly superior over $T_{3}, T_{4}, T_{5}$, $\mathrm{T}_{7}, \mathrm{~T}_{1}, \mathrm{~T}_{6}$ and $\mathrm{T}_{8}$ in reducing disease incidence at 55 DAS, 70 DAS and 85 DAS. The least disease incidence was observed in $\mathrm{T}_{2}$ i.e., hexaconazole at 55 DAS (55.49 per cent), 70 DAS (46.58 per cent) and 85 DAS (38.24 per cent) followed by $\mathrm{T}_{3}$ i.e., propiconazole at 55 DAS (45.36 per cent), 70 DAS (35.56 per cent) and 85 DAS (23.64 per cent), $\mathrm{T}_{4}$ i.e., penconazole at 55 DAS (48.68 per cent), 70 DAS (37.94 per cent) and 85 DAS (27.28 per cent), $\mathrm{T}_{5}$ i.e., wettable sulphur at 55 DAS (53.64 per cent), 70 DAS (42.49 per cent) and 85 DAS (33.15 per cent). The hexaconazale 5\% EC @ 0.1\%, propiconazole 10\% EC @ $0.1 \%$, penconazole $10 \%$ EC @ $0.1 \%$ and wettable sulphur 80 WP\% EC @ 0.3\%,under study were found to be significantly effective in management of the disease. Whereas, $\mathrm{T}_{1}$ (carbendazim 50\% WP @ 0.1\%), $\mathrm{T}_{7}$ (Mancozeb 75WP 0.1\%) $\mathrm{T}_{6}$ (tridemorph 25\% WP @ $0.1 \%$ ) and showed significantly lowest disease incidence over control at 55 DAS, 70 DAS and 85 DAS.

\section{Per cent disease intensity (PDI)}

The powdery mildew disease intensity (PDI) recorded at initiation stage i.e., before spraying was ranged from 11.24 per cent to 16.74 per cent. Three sprays of fungicides was undertaken at 55 DAS, 70 DAS and 85 DAS with on interval of the disease as recorded after each spraying from each treatment was worked out and is given in Table 2.

\section{Effect of first spraying on PDI}

The results given in Table 2 revealed that all the fungicides used in the experiment significantly reduced disease intensity as compared to control/check. Treatment hexaconazole (42.51 per cent), propiconazole (45.36 per cent), penconazole (48.68 per cent) and Sulfex (53.64 per cent) was found to be 
significantly superior over rest of the fungicides in controlling the per cent disease intensity. The other treatments that followed in the order of merit were carbendazim (48.68 Per cent), tridemorph (58.34 Per cent) and Mancozeb (53.64 Per cent).

\section{Effect of second spraying on PDI}

The treatment hexaconazole (31.21 per cent) was significantly superior over all other fungicides in reducing the per cent disease intensity. Treatment propiconazole (35.56 per cent) was the second best which was also significantly superior over all other fungicides in reducing disease intensity. Treatment penconazole (37.94 per cent) and treatment wetabal sulphur (42.49 per cent) ranked third and fourth. The order of merit of other fungicides was carbendazim (46.58 per cent), tridemorph (56.43 per cent), and Mancozeb (52.65 per cent) respectively.

\section{Effect of third spraying on PDI}

After third spraying, hexaconazole was found superior over all other treatments in reducing powdery mildew intensity (19.46 per cent). Treatment propiconazole (23.64 per cent), penconazole (27.28 per cent) and wetable sulphur (34.15 per cent) were the second, third and fourth best fungicides in reducing disease intensity. The order of merit of other fungicides was carbendazim (38.24 per cent) tridemorph (46.35 per cent) and Mancozeb (49.18 per cent).

\section{Mean per cent disease intensity (PDI) after sprayings}

It is clear from the results (Table 2) that there was a continuous decrease in per cent disease intensity in all fungicidal applications after each sprayings. The minimum per cent disease intensity was observed in hexaconazole (27.30 per cent) followed by propiconazole (30.92 per cent), penconazole (34.93 per cent) and wetable sulphur (40.43 per cent). The sprays of carbendazim (44.5 per cent), tridemorph (53.70 per cent) and Mancozeb (41.26 per cent) also reduced the per cent disease. As compared to check/control and per cent disease control as revealed after third spraying are graphically expressed in Figure 2.

Fungicide used in experiment

\begin{tabular}{|c|c|c|c|c|c|}
\hline $\begin{array}{l}\text { Sr } \\
\text { No. }\end{array}$ & Common name & $\begin{array}{c}\text { Trade name, } \\
\text { Active } \\
\text { ingredient }\end{array}$ & $\begin{array}{l}\text { Conc. } \\
\text { Used }\end{array}$ & $\begin{array}{l}\text { Price } \\
\text { (Rs) }\end{array}$ & Manufacturer \\
\hline 1. & Carbendazim & Bavistin 50\% WP & $0.1 \%$ & $800 / \mathrm{kg}$ & BASF India Ltd. Mumbai \\
\hline 2. & Hexaconazole & Contaf $5 \% \mathrm{EC}$ & $0.1 \%$ & 572/ lit & Syngenta Ltd, Mumbai \\
\hline 3. & Propiconazole & $\begin{array}{c}\text { Tilt } \\
10 \% \mathrm{EC}\end{array}$ & $0.1 \%$ & 1328/lit & Syngenta Ltd, Mumbai \\
\hline 4. & Penconazole & Topas $10 \%$ EC & $0.1 \%$ & 1700/lit & Rallis India Ltd, Mumbai \\
\hline 5. & Wettable suphur & Sulfex $80 \%$ WP & $0.3 \%$ & $200 / \mathrm{kg}$ & Syngenta Ltd, Mumbai \\
\hline 6. & Tridemorph & Calixin $80 \% \mathrm{EC}$ & $0.05 \%$ & $700 / \mathrm{kg}$ & BASF India Ltd, Mumbai \\
\hline 7. & Mancozeb & $\begin{array}{c}\text { Dithane M-45 } \\
75 \% \mathrm{WP}\end{array}$ & $0.05 \%$ & 1800/lit & Syngenta Ltd., Mumbai \\
\hline
\end{tabular}


Table.1 Efficacy of fungicides on disease incidence of powdery mildew of cucumber

\begin{tabular}{|c|c|c|c|c|c|}
\hline \multirow[t]{2}{*}{ Tr. No. } & \multirow[t]{2}{*}{ Treatment details } & \multirow[t]{2}{*}{ Conc. } & \multicolumn{3}{|c|}{ Disease incidence (\%) } \\
\hline & & & 55 DAS & 70 DAS & 85 DAS \\
\hline$\overline{T_{1}}$ & $\begin{array}{l}\text { Carbendazim } \\
50 \% \text { WP. }\end{array}$ & $0.1 \%$ & $\begin{array}{l}55.49 * \\
(48.15)\end{array}$ & $\begin{array}{l}46.58 \\
(43.03)\end{array}$ & $\begin{array}{c}38.24 \\
(38.19)\end{array}$ \\
\hline$\overline{T_{2}}$ & $\begin{array}{l}\text { Hexaconazole } \\
5 \% \text { EC. }\end{array}$ & $0.1 \%$ & $\begin{array}{c}42.51 \\
(40.69)\end{array}$ & $\begin{array}{c}31.21 \\
(33.96)\end{array}$ & $\begin{array}{c}19.46 \\
(26.17)\end{array}$ \\
\hline $\mathbf{T}_{3}$ & $\begin{array}{l}\text { Propiconazole } \\
10 \% \text { EC. }\end{array}$ & $0.1 \%$ & $\begin{array}{c}45.36 \\
(42.33)\end{array}$ & $\begin{array}{c}35.56 \\
(36.60)\end{array}$ & $\begin{array}{c}23.64 \\
(29.09)\end{array}$ \\
\hline$\overline{T_{4}}$ & $\begin{array}{l}\text { Penconazole } \\
10 \% \text { EC }\end{array}$ & $0.1 \%$ & $\begin{array}{c}48.68 \\
(44.24)\end{array}$ & $\begin{array}{c}37.94 \\
(38.02)\end{array}$ & $\begin{array}{c}27.28 \\
(31.48)\end{array}$ \\
\hline $\mathbf{T}_{5}$ & $\begin{array}{l}\text { Wetable sulphur } \\
80 \% \text { WP }\end{array}$ & $0.3 \%$ & $\begin{array}{c}53.64 \\
(47.08)\end{array}$ & $\begin{array}{c}42.49 \\
(40.08)\end{array}$ & $\begin{array}{c}33.15 \\
(35.15)\end{array}$ \\
\hline$T_{6}$ & $\begin{array}{l}\text { Tridemorph } \\
25 \% \text { EC }\end{array}$ & $0.05 \%$ & $\begin{array}{c}65.32 \\
(53.92)\end{array}$ & $\begin{array}{c}56.43 \\
(48.69)\end{array}$ & $\begin{array}{c}46.35 \\
(42.90)\end{array}$ \\
\hline $\mathbf{T}_{7}$ & $\begin{array}{l}\text { Mancozeb } \\
75 \% \text { WP }\end{array}$ & $0.05 \%$ & $\begin{array}{c}61.24 \\
(51.49)\end{array}$ & $\begin{array}{c}52.65 \\
(46.51)\end{array}$ & $\begin{array}{c}41.26 \\
(39.96)\end{array}$ \\
\hline $\mathbf{T}_{8}$ & Control & & $\begin{array}{c}68.3 \\
(55.49)\end{array}$ & $\begin{array}{c}76.28 \\
(60.85)\end{array}$ & $\begin{array}{c}86.44 \\
(68.39)\end{array}$ \\
\hline & S.E. \pm & & 2.25 & 1.34 & 0.96 \\
\hline & C.D. $(\mathrm{P}=0.05)$ & & 6.57 & 3.91 & 2.81 \\
\hline
\end{tabular}

*Average of three replications.

Figure of parenthesis are angular transformed values.

Table.2 Efficacy of fungicides on disease intensity (PDI) and (PDC) of powdery mildew on cucumber

\begin{tabular}{|c|c|c|c|c|c|c|c|c|c|c|c|}
\hline \multirow{2}{*}{$\begin{array}{l}\text { Tr. } \\
\text { No }\end{array}$} & \multirow{2}{*}{$\begin{array}{l}\text { Treatment } \\
\text { details }\end{array}$} & \multirow[t]{2}{*}{ Conc. } & \multirow{2}{*}{$\begin{array}{c}\text { PDI" } \\
\text { before } \\
\text { spraying }\end{array}$} & \multicolumn{3}{|c|}{ PDI* after spraying } & \multirow{2}{*}{$\begin{array}{l}\text { Mean } \\
\text { PDI }\end{array}$} & \multicolumn{3}{|c|}{ PDC $^{*}$ after sprayings } & \multirow{2}{*}{$\begin{array}{l}\text { Mean } \\
\text { PDC }\end{array}$} \\
\hline & & & & First & Second & Third & & First & Second & Third & \\
\hline$\overline{T_{1}}$ & $\begin{array}{l}\text { Carbendazim } \\
50 \% \text { WP. }\end{array}$ & $0.1 \%$ & $\begin{array}{c}16.38 \\
(23.87)\end{array}$ & $\begin{array}{c}48.68 \\
(44.24)\end{array}$ & $\begin{array}{c}46.58 \\
(43.03)\end{array}$ & $\begin{array}{c}38.24 \\
(38.19)\end{array}$ & $\begin{array}{c}44.5 \\
(41.84)\end{array}$ & $\begin{array}{c}20.42 \\
(26.86)\end{array}$ & $\begin{array}{c}38.93 \\
(38.60)\end{array}$ & $\begin{array}{c}55.76 \\
(48.30)\end{array}$ & $\begin{array}{c}38.37 \\
(38.27)\end{array}$ \\
\hline$\overline{T_{2}}$ & $\begin{array}{l}\text { Hexaconazole } \\
5 \% \text { EC. }\end{array}$ & $0.1 \%$ & $\begin{array}{c}15.47 \\
(23.16)\end{array}$ & $\begin{array}{c}31.25 \\
(33.98)\end{array}$ & $\begin{array}{c}31.21 \\
(33.96)\end{array}$ & $\begin{array}{l}19.46 \\
(26.17)\end{array}$ & $\begin{array}{l}27.30 \\
(31.49)\end{array}$ & $\begin{array}{c}49.00 \\
(44.42)\end{array}$ & $\begin{array}{c}59.08 \\
(50.30)\end{array}$ & $\begin{array}{c}77.48 \\
(61.66)\end{array}$ & $\begin{array}{r}61.85 \\
(51.85)\end{array}$ \\
\hline $\mathbf{T}_{3}$ & $\begin{array}{l}\text { Propiconazole } \\
10 \% \text { EC. }\end{array}$ & $0.1 \%$ & $\begin{array}{c}18.24 \\
(25.28)\end{array}$ & $\begin{array}{c}33.58 \\
(35.41)\end{array}$ & $\begin{array}{c}35.56 \\
(63.60)\end{array}$ & $\begin{array}{c}23.64 \\
(28.97)\end{array}$ & $\begin{array}{c}30.92 \\
(33.78)\end{array}$ & $\begin{array}{c}45.20 \\
(42.24)\end{array}$ & $\begin{array}{c}53.38 \\
(46.93)\end{array}$ & $\begin{array}{l}72.65 \\
(58.46)\end{array}$ & $\begin{array}{c}57.07 \\
(49.06)\end{array}$ \\
\hline$T_{4}$ & $\begin{array}{l}\text { Penconazole } \\
10 \% \text { EC }\end{array}$ & $0.1 \%$ & $\begin{array}{c}11.24 \\
(19.58)\end{array}$ & $\begin{array}{c}39.58 \\
(38.98)\end{array}$ & $\begin{array}{c}37.94 \\
(38.02)\end{array}$ & $\begin{array}{l}27.28 \\
(31.48)\end{array}$ & $\begin{array}{c}34.93 \\
(36.22)\end{array}$ & $\begin{array}{c}35.41 \\
(36.51)\end{array}$ & $\begin{array}{c}50.26 \\
(45.14)\end{array}$ & $\begin{array}{c}68.44 \\
(55.82)\end{array}$ & $\begin{array}{c}51.37 \\
(45.78)\end{array}$ \\
\hline $\mathbf{T}_{5}$ & $\begin{array}{l}\text { Wetable sulphur } \\
80 \% \text { WP }\end{array}$ & $0.3 \%$ & $\begin{array}{c}13.64 \\
(21.67)\end{array}$ & $\begin{array}{c}44.65 \\
(41.92)\end{array}$ & $\begin{array}{c}42.49 \\
(40.68)\end{array}$ & $\begin{array}{c}34.15 \\
(35.75)\end{array}$ & $\begin{array}{c}40.43 \\
(39.48)\end{array}$ & $\begin{array}{c}27.13 \\
(31.39)\end{array}$ & $\begin{array}{c}44.29 \\
(41.72)\end{array}$ & $\begin{array}{c}60.49 \\
(51.05)\end{array}$ & $\begin{array}{c}43.97 \\
(51.53)\end{array}$ \\
\hline$T_{6}$ & $\begin{array}{l}\text { Tridemorph } \\
25 \% \text { EC }\end{array}$ & $0.05 \%$ & $\begin{array}{c}14.57 \\
(22.43)\end{array}$ & $\begin{array}{c}58.34 \\
(49.80)\end{array}$ & $\begin{array}{c}56.43 \\
(48.69)\end{array}$ & $\begin{array}{c}46.35 \\
(42.96)\end{array}$ & $\begin{array}{c}53.70 \\
(47.12)\end{array}$ & $\begin{array}{c}4.79 \\
(12.64)\end{array}$ & $\begin{array}{c}26.02 \\
(30.67)\end{array}$ & $\begin{array}{c}46.37 \\
(42.91)\end{array}$ & $\begin{array}{c}25.72 \\
(30.47)\end{array}$ \\
\hline $\mathbf{T}_{7}$ & $\begin{array}{l}\text { Mancozeb } \\
75 \% \text { WP }\end{array}$ & $0.05 \%$ & $\begin{array}{l}16.98 \\
(24.33)\end{array}$ & $\begin{array}{c}53.64 \\
(47.08)\end{array}$ & $\begin{array}{c}52.65 \\
(48.82)\end{array}$ & $\begin{array}{c}41.26 \\
(39.96)\end{array}$ & $\begin{array}{c}49.18 \\
(44.53)\end{array}$ & $\begin{array}{c}12.46 \\
(20.67)\end{array}$ & $\begin{array}{c}66.37 \\
(54.55)\end{array}$ & $\begin{array}{c}52.26 \\
(46.29)\end{array}$ & $\begin{array}{c}43.69 \\
(41.37)\end{array}$ \\
\hline $\mathbf{T}_{8}$ & Control & & $\begin{array}{c}16.74 \\
(24.15)\end{array}$ & $\begin{array}{c}61.28 \\
(51.51)\end{array}$ & $\begin{array}{c}76.28 \\
(60.85)\end{array}$ & $\begin{array}{c}86.44 \\
(68.39)\end{array}$ & $\begin{array}{l}74.66 \\
(59.77)\end{array}$ & $\begin{array}{c}00.00 \\
(00.00)\end{array}$ & $\begin{array}{c}00.00 \\
(00.00)\end{array}$ & $\begin{array}{c}00.00 \\
(00.00)\end{array}$ & $\begin{array}{c}00.00 \\
(00.00)\end{array}$ \\
\hline & S.E. \pm & & 0.48 & 0.70 & 0.69 & 0.65 & & 1.06 & 1.21 & 1.23 & \\
\hline & C.D. $(P=0.05)$ & & 1.42 & 2.05 & 2.03 & 1.90 & & 3.10 & 3.54 & 3.60 & \\
\hline
\end{tabular}

*Average of three replications.

PDI - Per cent disease

Intensity $\quad$ PDC - Per cent disease control

Figures of parenthesis are angular transformed values. 


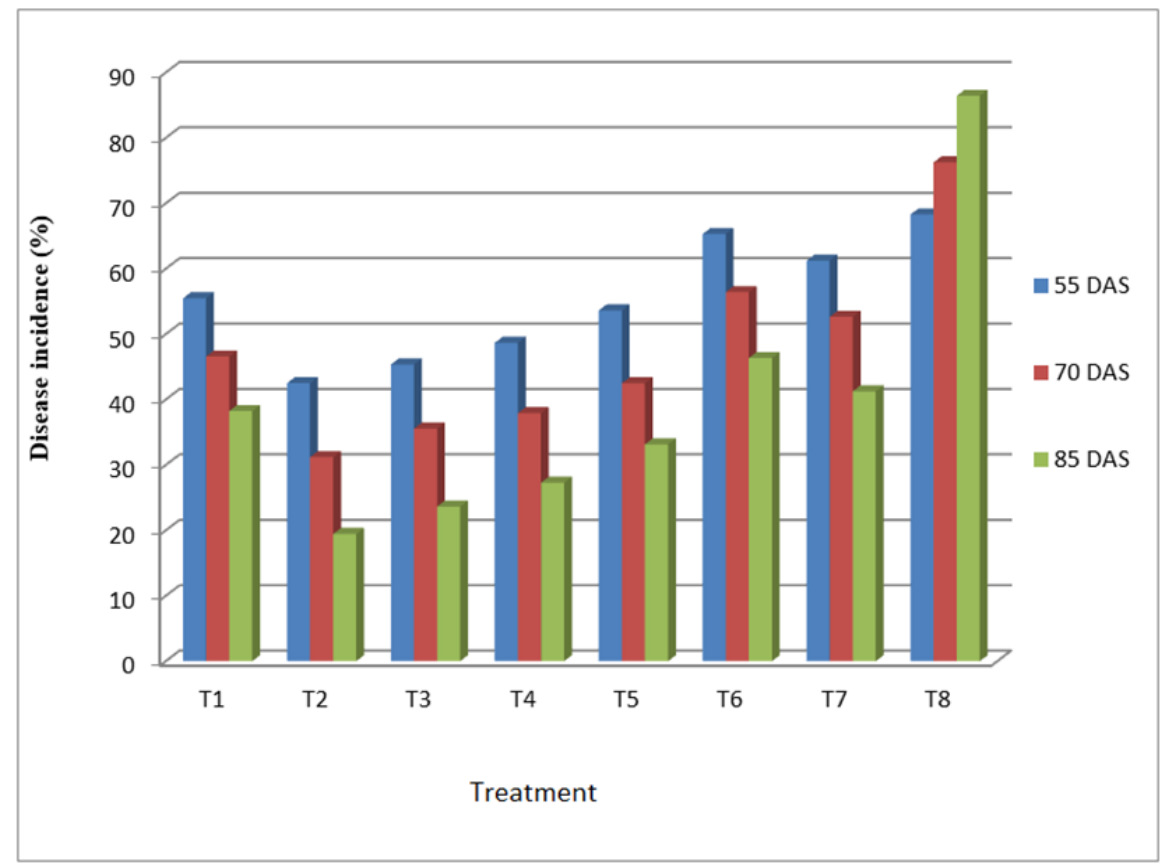

Fig:-1 Efficacy of fungicides on disease incidence of powdery mildew of Cucumber.

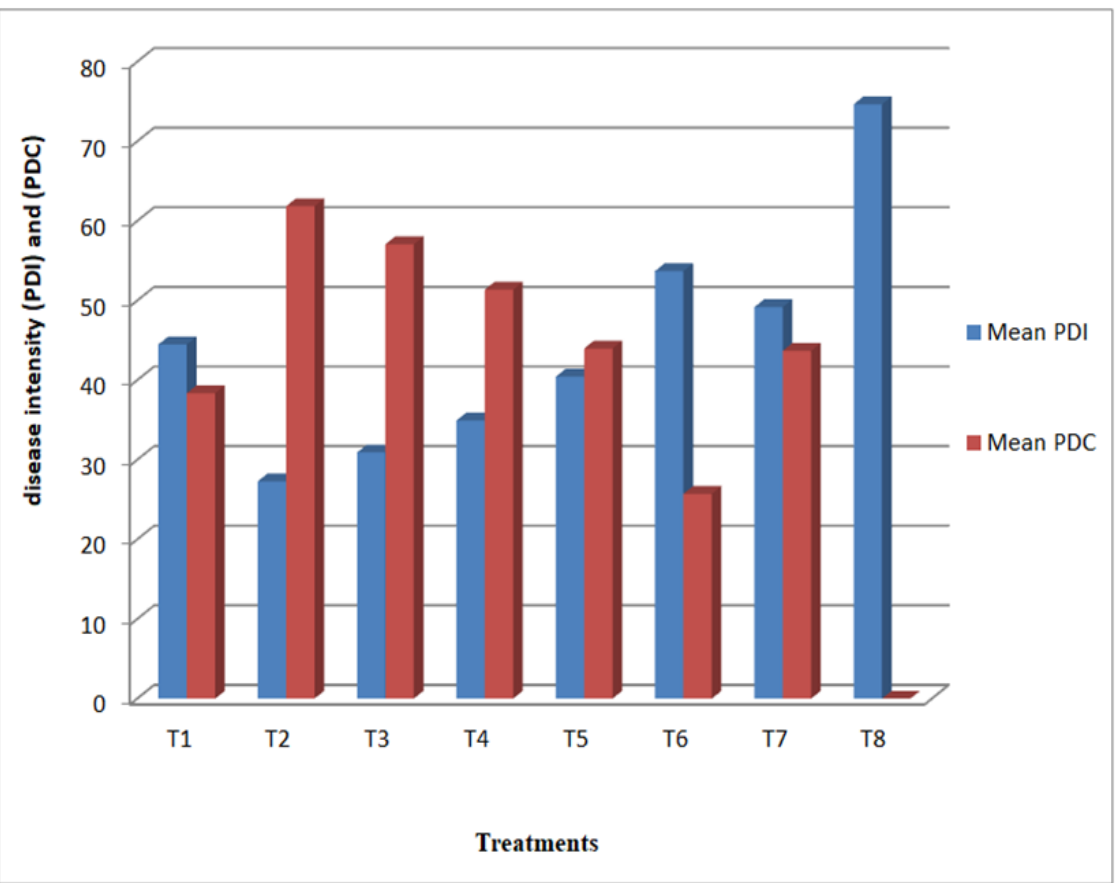

Fig :- 2 Efficacy of fungicides on disease intensity (PDI) and (PDC) of powdery mildew on Cucumber. 
Thus on the basis of effectiveness of all the treatments in controlling powdery mildew of Cucumber the most effective fungicide recorded in order of merit were hexaconazole $(0.1 \%)$, propiconazole $(0.1 \%)$ and penconazole $(0.1 \%)$ with good disease control.

Similar results given by several researchers like Khunti et al., (2005) proved that all the triazoles fungicides performed better as compare to conventional fungicides. The minimum disease intensity and highest yield was recorded with the application of hexaconazole and penconazole in green gram for management of powdery mildew. Shivanna et al., (2006) proved that fungicides penconazole followed by hexaconazole and propiconazole was found effective against powdery mildew of okra. Ashtaputre et al., (2007) proved that the powdery mildew disease in chilli was effectively controlled by using triazole groups of fungicides and recommended three sprays of hexaconazole $(0.1 \%)$ as more useful not only in reducing the cost of protection but also gave higher benefits as compared to other treatments. Prasad and Dwivedi (2007) reported that tilt (propiconozole $10 \mathrm{EC}$ ) was the most effective treatment, which not only increased seed yield but also reduced disease severity. Adinarayana et al., (2012) reported that penconazole $10 \mathrm{EC}$ was found significantly best triazole fungicide for management powdery mildew of urdbean. Amaresh et al., (2013) stated that hexaconazole 5 EC and propiconazole $10 \mathrm{EC}$ were best triazoles fungicides against sunflower powdery mildew.

\section{Per cent disease control (PDC) after spraying}

Per cent disease control (PDC) achieved after first, second and third spraying ranged from 4.79 per cent to 49 per cent, 26.02 per cent to
66.37 per cent and 46.37 per cent to 77.48 per cent, respectively. After third spraying maximum disease control was recorded in fungicides hexaconazole $(0.1 \%)$ to the tune of (77.48 per cent), followed by propiconazole (72.65 per cent), penconazole (68.44 per cent) and wetable sulphur (60.49 per cent). Similar trend of per cent disease control was observed after second spraying of fungicide hexaconazole (59.08 per cent), propiconazole (53.38 per cent), penconazole (50.26 per cent) and wetable sulphur (44.29 per cent) were ranked first, second, third and fourth in order of merit of disease control. Maximum mean disease control was obtained in hexaconazole (61.85 per cent) followed by propiconazole (57.07 per cent), penconazole (51.37 per cent) and wetable sulphur (43.97 per cent).

Mean disease control (PDC) was achieved with all the treatments (Table 2) ranged from 25.72 per cent to 61.85 per cent. The highest mean disease control was recorded in fungicide hexaconazole $(61.85 \%)$. The second, third and fourth best fungicides were propiconazole (57.07 per cent), penconazole (51.37 per cent) and wetable sulphur (43.97 per cent) respectively.

The effect of hexaconazole was noted curative and gave maximum disease control. Similar results were obtained by Khunti et al., (2005), Prasad and Dwivedi (2007) and Amaresh et al., (2013)

Results of field efficacy of fungicides against powdery mildew indicated that disease incidence and disease intensity were declined only after second and third sprays. Disease incidence and per cent disease intensity after third treatment spray (85 DAS) was recorded in the range of 19.46 to 41.26 per cent and 27.30 to 74.66 per cent PDI, respectively as against unsprayed control. The fungicide hexaconazole $(0.1 \%)$ showed significantly lowest disease incidence $(19.46 \%)$ and 
disease intensity $(27.30 \%)$ with maximum $(61.85 \%)$ mean per cent disease control. On the basis of effectiveness in controlling the powdery mildew disease of Cucumber, the most effective fungicides recorded in the order of merit were hexaconazole $(0.1 \%)$, propiconazole $(0.1 \%)$ and penconazole $(0.1$ $\%)$.

\section{References}

Anonymous (2007). Sunflower Annual progress report, AICRP, (Sunflower) Directorate of Oilseed Research, Hyderabad PP: 151-154.

Anonymous (2008). Sunflower Annual Progress report, AICRP (Sunflower) Directorate of Oilseed Research, Hyderabad pp: 138-165.

Bhatia, J. N. and Thakur, D. P. (1989). Field evaluation of systemic and nonsystemic fungicides against powdery mildew of different economic crops. Ind. phytopath, 42: 571-573.

Gawande, P.S. and Peshney, N.L. (1987). Seasonal incidence and chemical control of powdery mildew of bhendi. (Abemoschus esculentus L.) in uidarbha. PKV. Res J., 11(1): 54-57.

Joi, M.B. and Shende, R.V. (1979). Fungicidal Control of Powdery mildew of okra. Pesticides, 13: 32-34.
Khodke, S.W. and Kakde, S.U. (2004). Effect of chemicals and botonicals on powdery mildew of mustard (Brassica juncea L.). PKV. Res. J., 28(1): 61-63.

Naik, K.S and Nagaraja. A. (2003). Chemical control of powdery mildew of okra. Agric. Sci. Digest., 23(4): 305-306.

Naik, K.S. and Nagaraja, A. (2000). Chemical control of powdery mildew of okra. Ind. J. Pl. Prot., 28 (1) 41-42.

Rahman, M.A. and Bhattiprolu, S.L. (2005). Management of okra powdery mildew by fungicides. Karnataka J. Agric. Sci., 18(4):998-1002.

Ramkrishnan, L., Thamburaj, S. O., Kamalnath, S. and Krishnamirthy, C. S (1975). Effect of certain non-systemic fungicides powdery mildew disease of bhendi (A. esculantus) Madras Agric. J., 62 (1): 38-40.

Shridhar, T. S. and Sinha, P. (1989). Assessment of loss caused by powdery mildew (Erysiphe cichoracearum) of okra (Hibiscus esculentus) and it's control. Ind. J. Agric. Sci., 59 (9) 606607.

Vijaya, M. (2004). Chemical control of powdery mildew in okra. Ind. J. Mycol. Pl. Pathol. 34 (20): 604-605.

\section{How to cite this article:}

Wahul, S.M., G.P. Jagtap, K.A. Rewale and Bhosale, R.P. 2018. In vitro Evaluation of Various Fungicides against Erysiphe cichorocearum in Polyhouse. Int.J.Curr.Microbiol.App.Sci. 7(10): 1611-1617. doi: https://doi.org/10.20546/ijcmas.2018.710.182 